строків застосування («безстроково»), а по суті - відмова від тимчасовості (наприклад, Указ Президента України від 27.02.2021 № 81/2021), а також фактично щотижневі рішення про застосування заходів (особливо, протягом лютого-квітня 2021 року). Зазначені вище фактори дозволяють визначення з 01.02.2021 наступного - третього етапу розвитку законодавства.

Отже, підсумовуюче викладене, варто визнати, що цілком можливо провести періодизацію вітчизняного законодавства щодо індивідуальних обмежувальних заходів, виокремивши принаймні два етапи. Наявність та хронологічні рамки третього є підставою для подальших наукових дискусій.

\title{
Література:
}

1. Доронін I.М. Національна безпека України в інформаційну епоху: теоретико-правове дослідження: автореф. дис. ... докт. юрид. наук. Київ, 2020. С. 26.

2. Birkhauser N. Sanctions of the Security Council against Individuals - Some Human Rights Problems URL: www.esil-sedi.eu/sites/default/files/Birkhauser.PDF (Last accessed: 24.12.2020).

DOI https://doi.org/10.30525/978-9934-26-148-0-31

\section{ОСОБЛИВОСТІ ОФОРМЛЕННЯ КОНТРАКТІВ В КІБЕРСПОРТІ ВІДПОВІДНО ДО УКРАЇНСЬКОГО ЗАКОНОДАВСТВА}

\author{
Косохатько Б. С. \\ магістр Інституту права \\ Київького національного університету імені Тараса Шевченка \\ м. Київ, Україна
}

Щодня перед світовою спільнотою постають нові виклики, які зазвичай потребують сучасного та швидкого рішення. Доволі часто такі рішення є цифровими: починаючи від надання державних послуг і закінчуючи онлайн освітою та медициною.

Цифровізація та інтереси молодого покоління не оминули й сучасний спорт. Вже сьогодні можна побачити, як улюблений футболіст збірної футболу України та професійний кіберспортсмен українського клубу грають в один 3 найвідоміших онлайн шутерів. Такі події не залишаються без уваги широкого кола людей, а тому збирають сотні 
тисяч прихильників з усього світу. За такими подіями прихована не лише гарна картинка та цікавий контент, а й команди гравців, їх медіастратегії, менеджери, промоутери, маркетологи, юристи та найголовніше про що треба згадати - певні правовідносини, які серед усього пов'язують професійних кібергравців з командами, грою та вже згаданими раніше глядачами.

Як правило, такі правовідносини в електронному спорті (гравців та команд) закріплюються нічим іншим, як контрактами, тобто, особливою формою трудового договору. За аналогією, як це відбувається в футболі, тенісі, баскетболі чи іншому добре відомому нам виду спорті. Проте, чи мають такі контракти так багато спільного з тим, що $є$ у звичайному спорті?

Зрозуміло, що такі контракти, хоч i мають схожу природу 3 контрактами у класичному спорті, проте, вони не є аналогічними та мають свої відмінні характерні риси. Постає питання чи ідеально забезпечені нормативно правовою базою правовідносини у звичайному спорті та чи поширюються вони на кіберспорт?

Насправді питання врегулювання трудових відносин у такій специфічній сфері як професійний спорт потребує вдосконалення, оскільки станом на сьогодні основний національний закон у галузі спорту - Закон України «Про фізичну культуру і спорт» від 24.12.1993 р. №3808-XII (далі - Закон) - стосується лише загальних основ діяльності у сфері фізичної культури та спорту, регулює суспільні відносини у створенні умов для розвитку фізичної культури та спорту, а також не містить навіть прийнятного визначення такого поняття як контракт із професійним спортсменом.

У ст. 38 цього Закону зазначено, що діяльність у професійному спорті спортсменів, тренерів та інших фахівців, яка полягає у підготовці та участі у спортивних змаганнях серед спортсменів-професіоналів і $\epsilon$ основним джерелом їхніх доходів, провадиться відповідно до цього Закону, Кодексу законів про працю України та інших нормативноправових актів, а також статутних та регламентних документів відповідних суб'єктів сфери фізичної культури та спорту й міжнародних спортивних організацій [1].

Слідуючи логіці законодавця в статті 38 вищезгаданого Закону ми повинні звернути свою увагу на частину 3 статті 21 Кодексу законів про працю, де передбачено, що особливою формою трудового договору $\epsilon$ контракт, в якому строк його дії, права, обов'язки й відповідальність сторін (в тому числі матеріальна), умови матеріального забезпечення та організації праці працівника, умови розірвання договору, в тому числі дострокового, можуть встановлюватися угодою сторін. Сфера 
застосування контракту визначається законами України [2]. В нашому випадку сферою застосування є спорт.

Звідси слідує, що якщо кіберспортсмен $є$ справді професійним спортсменом, то в такому разі на нього поширюється дія законів України, в тому числі Кодекс законів про працю України. I хоча положення законодавства про класичний спорт не ідеальні, проте вони вже додають певне нормативне підгрунтя для сфери електронного спорту.

А враховуючи те, що Наказом Міністерства молоді та спорту України від 16.09.2020 № 1557 кіберспорт було визнано офіційним видом спорту в Україні [3], то це означає, що на кіберспортсменів поширюються аналогічні положення законодавства (обов'язки, статуси, права, гарантії, в тому числі трудові), що і на всіх спортсменів України інших видів спорту.

Аналізуючи практику застосування трудових договорів в інших видах спорту можна також побачити деяку особливість, яка полягає в тому, що в деяких дисциплінах (переважно командних) існує локальне імперативне тлумачення поняття «контракт» відповідною профільною організацією.

Для прикладу, ми можемо віднайти це в статті 11 Регламенту «Чемпіонату України 3 хокею 3 шайбою - Чемпіонату Української хокейної ліги сезону 2017-2018 років», затвердженого ТОВ «Українська хокейна ліга» та погодженого ВГО «Федерація хокею України».

Схожу практику можна знайти й в Регламенті Всеукраїнських змагань 3 футболу серед команд клубів Професіональної футбольної ліги сезону 2017/18, затвердженого конференцією Об'єднання футбольних клубів «Професійна футбольна ліга України» та виконавчим комітетом Громадської спілки «Федерація футболу України».

Що ж стосується індивідуальних видів спорту, то усталеною $є$ практика, коли спортсмена залучають для конкретних змагань і тоді між ним та організацією існують цивільноправові відносини, які не мають жодного імперативного характеру та не є навіть схожими на трудові.

Чи можливо використати таку практику в кіберспорті? Насправді такий підхід не доцільно застосовувати в кіберспортивній галузі, оскільки на відміну від футболу чи хокею - кіберспорт об'єднує в собі велику кількість різноманітних дисциплін, кожна 3 яких потребує окремих навичок, різноманіття команди та $\epsilon$ особливою за своєю механікою гри. Наприклад, в дисципліні «Dota 2» команда потребує 5 гравців різних ролей та тренера і вважається командним видом спорту, тож для неї доцільно застосовувати модель «працівник-роботодавець» 3 усіма перевагами трудових відносин. Водночас така дисципліна, як «Hearthstone» потребує всього одного гравця, який може навіть не 
представляти клуб та не мати тренера i бути індивідуальним спортсменом. Щоправда, це часто не стає на заваді для деяких кіберспортивних клубів і вони все одно наймають такого гравця в штат за трудовим контрактом.

Тож, як ми бачимо, кіберспорт є достатньо розрізненою сферою i видом спорту, який має свої надто відмінні особливості, в яких неможливо застосувати шаблонні правила чи конструкції.

Окрім того, є також деякі особливості умов контрактів 3 кіберспортсменами, які не $\epsilon$ типовими для інших видів спорту та українського трудового законодавства.

Доволі часто контракти у сфері кіберспорту передбачають дещо незвичні положення, які стосуються образу життя та дій які повинен вчиняти або не вчиняти кіберспортсмен. Наприклад, під час проведення турніру «WePlay! Bukovel Minor 2020» в контрактах багатьох спортсменів була передбачена заборона катання на лижах чи участь в інших зимових розвагах. Також, доволі часто, окрім тренувань, в контрактах передбачають умови, що стосуються медіа складової життя спортсмена: проведення певної кількості прямих трансляцій під час тренувань, проведення певної кількості фотосесій, гра на певній ролі протягом певного часу та інші.

Підсумовуючи, можна зазначити, що сфера кіберспорту на сьогодні $\epsilon$ недостатньо забезпечена нормативно-правовою базою з законодавчої точки зору не дивлячись на те, що вона вважається перспективною та прибутковою. Так, за даними провідної аналітичної компанії «Newzoo» сумарний прибуток від кіберспорту у всьому світі за 2021 рік має сягнути більше мільярда доларів [4].

\section{Лiтература:}

1. Юридична газета №36 (638) від 04.09.2018 URL: https://yur-gazeta.com/publications/practice/sportivne-pravo/kontraktzi-sportsmenom--trudoviy-dogovir.html (дата звернення: 29.09.2021).

2. Кодекс законів про працю України: Закон України № 322-VIII / Верховна Рада України. URL: https://zakon.rada.gov.ua/laws/show/322-08 (дата звернення: 29.09.2021).

3. Наказ Міністерства молоді та спорту України від 16.09.2020 № 1557 / Міністерство молоді та спорту України. URL: https://zakon.rada.gov.ua/rada/show/v1557924-20 (дата звернення: 29.09.2021).

4. Інтернет-журнал «Cybersport.ru» від 09.03.2021 URL: https://www.cybersport.ru/other/news/newzoo-summarnaya-pribylkibersporta-v-2021-godu-prevysit-milliard-dollarov (дата звернення 29.09.2021). 